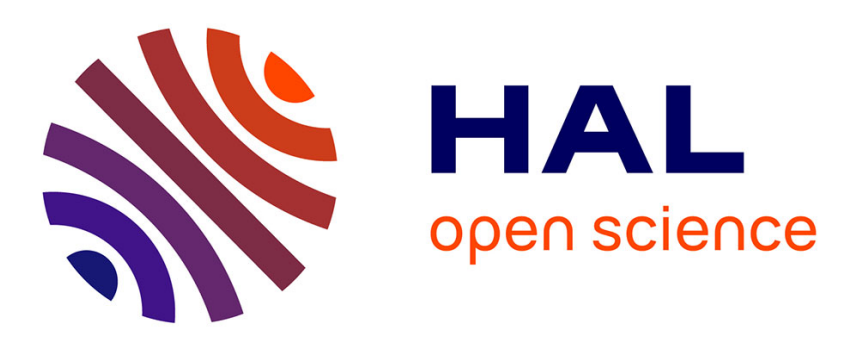

\title{
Relative contribution of the main tissues and organs to body fatty acid synthesis in the rat \\ Gilles Gandemer, G. Durand, G. Pascal
}

\section{To cite this version:}

Gilles Gandemer, G. Durand, G. Pascal. Relative contribution of the main tissues and organs to body fatty acid synthesis in the rat. Lipids, 1983, 18 (3), pp.223-228. hal-02720285

\section{HAL Id: hal-02720285 \\ https: / hal.inrae.fr/hal-02720285}

Submitted on 1 Jun 2020

HAL is a multi-disciplinary open access archive for the deposit and dissemination of scientific research documents, whether they are published or not. The documents may come from teaching and research institutions in France or abroad, or from public or private research centers.
L'archive ouverte pluridisciplinaire $\mathbf{H A L}$, est destinée au dépôt et à la diffusion de documents scientifiques de niveau recherche, publiés ou non, émanant des établissements d'enseignement et de recherche français ou étrangers, des laboratoires publics ou privés. 


\section{Relative Contribution of the Main Tissues and Organs to Body Fatty Acid Synthesis in the Rat}

G. GANDEMER, G. DURAND* and G. PASCAL, Institut National de la Recherche Agronamique, Centre National de Recherches Zootechniques, Station de Recherches de Nutrition, Domaine de Vilvert, 78350 Jouy-n-Josas, France

\section{ABSTRACT}

Tritiated water was used to measu te the rate of fatty acid synthesis in the main tissues and organs of 7-week old Wistar male rats in order to determine the relative contribution of each tissue to body fatty acid synthesis. We reached the following conclusions: (a) the liver is the main site of fatty acid synthesis, it alone synthesizes $42 \%$ of the newly synthesized fatty acids in the body. (b) The dissectable white adipose tissues synthesize $27 \%$ of the fatty acids in the body. This group of tissues is heterogeneous because the mesenteric adipose tissue alone contains $40 \%$ of the labeled fatty acids present in the white adipose tissues. (c) Besides the intestines, organs other than the liver play a negligible role (2\% of the total) in fatty acid synthesis. (d) The skin contributes $7 \%$ of the body fatty acid synthesis. (e) The rest of the carcass, essentially composed of the musculature and the skeleton, con. tributes $18 \%$ of body fatty acid synthesis and accounts for $33 \%$ of the extrahepatic tissue fatty acid synthesis.

Lipids 18:223-228, 1983.

For a long time, the relative contribution of the main tissues and organs to fatty acid synthesis in the body has been difficult to assess, due to methodological problems. A method was needed for measuring the total rate of fatty acid synthesis in each tissue independently of the origin of the carbon atoms incorporated into the fatty acids. The measurement of the incorporation of the ${ }^{3} \mathrm{H}$ of ${ }^{3} \mathrm{H}_{2} \mathrm{O}$ into fatty acids meets this need $(1,2)$. Using this tracer, liver contribution to body synthesis of fatty acids was estimated as $10-50 \%$ in rats (3-5) and mice (6-9), depending on the nutritional conditions.

By measuring the rate of fatty acid synthesis in the main tissues and ofgans of the mouse, it has been determined that the muscles are the main site of fat synthesis (some data 8,9 ). On the contrary, in rat, the role of the principal extrahepatic tissues and organs in fatty acid synthesis is still not well known; only the white adipose tissues have been widely studied $(4,5$, 9-11). These studies reported (a) that, at equal weight, the adipose tissues synthesized less fat than the liver $(4,5,9-11)$; and (b) that they contributed little to body fatty acid synthesis, at least in nonobese rats (4). Consequently, it seems that tissues other than the liver and white adipose tissues play an important part in lipogenesis in rats. In this study, we wished to determine accurately the main sites of fat synthesis in the rat by measuring the rate of the incorporation of the ${ }^{3} \mathrm{H}$ of ${ }^{3} \mathrm{H}_{2} \mathrm{O}$ into fatty acids in many tissues and organs.

*To whom correspondence should be addressed.

\section{METHODS}

\section{Animals and Diets}

We used 7-week old Wistar male rats having a mean live weight of $228 \mathrm{~g}$. From weaning at the age of 21 days, they are fed a semisynthetic diet containing $0.3 \%$ fat and $18 \%$ protein. The composition of the diet and the daily food intake of the animals has already been published (12). With this low-fat diet, we created the best conditions for observing de novo fatty acid synthesis $(13,14)$.

The rats were reared in a room on a $12 \mathrm{hr}$ dark $/ 12 \mathrm{hr}$ light cycle at a temperature of $22 \mathrm{C}$. The dark period extended from 3 A.M. to 3 P.M., so that when the animals were killed at 9-10 A.M., fat synthesis was at its highest in the tissues and organs (15).

Many studies have shown that catecholamines induce or stimulate lipolysis in different tissues (liver, muscle, adipose tissues). It is quite probable that simultaneously they check or inhibit lipogenesis. Therefore, when rats are stressed by handling and injection of ${ }^{3} \mathrm{H}_{2} \mathrm{O}$, causing increased catecholamine secretion, the synthesis of tissue and organ lipids studied may be affected. To keep the influence of this putative factor at a minimum, the rats used in this study were handled every day; moreover, intraperitoneal injection of ${ }^{3} \mathrm{H}_{2} \mathrm{O}$ was chosen, as it is almost painless, easy and quick to practise, and therefore least perturbing for the animals.

In vivo Measurement of Fatty Acid Synthesis

For measuring the rate of ${ }^{3} \mathrm{H}$ incorporation 
into the fatty acids of the main tissues and organs, each animal was given one intraperitoneal injection of ${ }^{3} \mathrm{H}_{2} \mathrm{O}(2.5 \mathrm{mCi}$ in $0.4 \mathrm{ml}$ of a $0.9 \%$ solution of $\mathrm{NaCl}$ ), immediately returned to its cage, and killed by decapitation $10 \mathrm{~min}$ later.

We chose to leave a 10 -min interval between the time the radioactive tracer was injected and the time the animals were killed; this choice was based on the following observations: (a) ${ }^{3} \mathrm{H}$ incorporation into the fatty acids of the tissues studied (liver, adipose tissues and rest of carcass) varied almost linearly in time for at least $60 \mathrm{~min}$ after injection (16), proving that ${ }^{3} \mathrm{H}$ specific radioactivity of water remained constant in each of these tissues during that time. These conditions are characteristic of the technique of radioactive tracer perfusion. (b) Moreover, ${ }^{3} \mathrm{H}$ specific radioactivity of plasma water became very similar to mean ${ }^{3} \mathrm{H}$ specific activity of body water (obtained by lyophilization) in the $3 \mathrm{~min}$ following injection and remained that way for at least $120 \mathrm{~min}$ (Fig. 1). This let us presume that ${ }^{3} \mathrm{H}$ specific radioactivity of water could be considered to be uniform in all tissues during this interval of 3-120 min. (c) As to the question of fatty acid exchange among the tissues, the profile of ${ }^{3} \mathrm{H}$ specific radioactivity in plasma total fatty acids in relation to time (Fig. 2) shows that the export of labeled

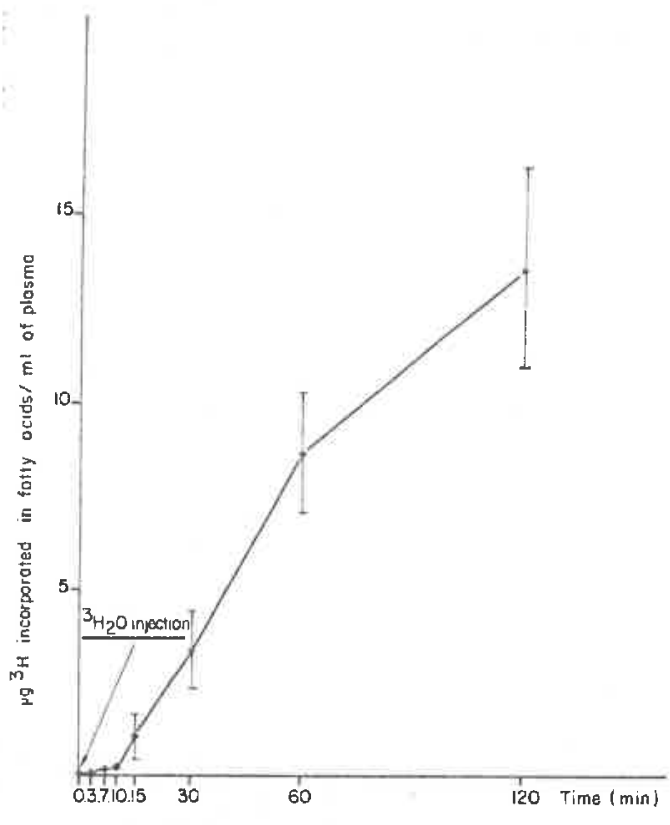

FIG. 2. Kinetics of specific total fatty acid radioactivity in plasma. Lots of 6-8 rats were decapitated immediately, $3,7,10,15,30,60$ and $120 \mathrm{~min}$ after intraperitoneal injection of a single dose $(2.5 \mathrm{mCi} /$ animil) of tritiated water. Specific fatty acid radioactivity is shown in $\mu \mathrm{g}$ of ${ }^{3} \mathrm{H}$ incorporated in to fatty acids/ml of plasma at each time. Each point is the mean \pm SD of 6-8 assays.

fatty acids into blood was minimal during the $10 \mathrm{~min}$ following tracer injection and would not modify, the estimate of the amounts of lipids synthesized in situ in each tissue. After $15 \mathrm{~min}$, the quantity of plasma labeled fatty acids increased rapidly, making possible important exchange among the different tissues.

Finally, considering all data, the chosen 10 minute interval appeared to be sufficient to obtain uniform distribution of ${ }^{3} \mathrm{H}_{2} \mathrm{O}$ in the rat organism and linearity of ${ }^{3} \mathrm{H}$ incorporation into fatty acids over tissue. However, it appeared as well that it is not advisable to exceed this time lapse by too much, to avoid a risk of intercellular exchange.

FIG. 1. Time-course of specific ${ }^{3} \mathrm{H}$ radioactivity in plasma water relative to ${ }^{3} \mathrm{H}$ radioactivity in body water. Lots of $6-8$ rats were decapitated immediately, $3,7,10,15,30,60$ and $120 \mathrm{~min}$ after intraperitoneal injection of a single dose $(2.5 \mathrm{mCi} / \mathrm{animal})$ of tritiated water. Specific radioactivity of plasma and body water was determined by direct counting of $25 \mu \mathrm{l}$ of water in scintillating liquid. The specific radioactivity is shown in $\mathrm{dpm} / \mathrm{L} \mu \mathrm{g}$ of ${ }^{3} \mathrm{H}$ at each time.

LIPIDS, VOL. 18, NO. 3 (1983)

\section{Sampling of Tissues and Organs}

After bleeding, the animal was skinned. The liver, heart, kidneys, lungs, puncreas, thymus, stomach, small and large intestines, brain and testes were dissected out and weighed. Depending on their anatomical location, the white adipose tissues were divided into 2 groups: 3 inner tissues (mesenteric, perirenal, epididymal) 
and 3 outer tissues (dorsal subcutaneous and inguinal, other adipose tissues). "Other adipose tissues" included the whole of the cover fat remaining after the dorsal subcutaneous and inguinal adipose tissues were taken. The rest of the carcass included the musculature and the skeleton. The tissues and organs were immersed in liquid nitrogen as soon as they were dissected.

\section{Measurement of ${ }^{3} \mathrm{H}$ Incorporation into Fatty Acids}

The skin and carcass were ground under nitrogen stream. Except for the white adipose tissues, the tissues, organs, skin and rest of the carcass were freeze-dried to eliminate most of the tritiated water. The total lipids were extracted from tissue or organ lyophilisates and from the fresh adipose tissues using the method of Folch et al. (17). The lower phase (chloroform) was thoroughly washed in distilled water to avoid any ${ }^{3} \mathrm{H}_{2} \mathrm{O}$ contamination of the fat. The weight and fat content of the liver, skin, adipose tissues and the rest of the carcass were enough to permit individual measurement of the specific radioactivity of the fats. For all the other tissues and organs, the fat was extracted from pools containing equal quantities of dry matter taken from the same organ of each animal.

After chloroform evaporation, we saponified $100-500 \mathrm{mg}$ of the total lipid extract in an alcoholic solution of $10 \%$ potassium hydroxide (w/w). The nonsaponifiable lipid was extracted by hexane and discarded. After acidification, the fatty acids were extracted by $3 \times 50 \mathrm{ml}$ of hexane. The 3 extracts were :grouped and the hexane evaporated. The fatty acids were dissolved in $4 \mathrm{ml}$ of hexane and transferred quantitatively into counting vials. After $8 \mathrm{ml}$ of scintillation fluid (Unisolve I Koch Light) was added, the radioactivity of each vial was measured in a "liquid scintillation counter." The quench corrections of each measurement was using the channel ratio. Specific radioactivity of the water ${ }^{3} \mathrm{H}$ was measured by counting $25 \mu \mathrm{l}$ of plasma. The specific radioactivity of the water ${ }^{3} \mathrm{H}$ of all the organs and tissues were presumed to equal that of the plasma water.

\section{Expression of Results}

The rate of fatty acid synthesis in each tissue and organ was expressed in $\mu \mathrm{g}$ of ${ }^{3} \mathrm{H}$ atom incorporated into the fatty acids $/ 10 \mathrm{~min} / \mathrm{g}$ of fresh tissue or per whole tissue. The results were computed using the ratio:

$\mathrm{dpm}$ incorporated into fatty acids $/ 10 \mathrm{~min} / \mathrm{g}$ -or per whole tissue

$\mathrm{dpm}$ in $1 \mu \mathrm{g}$ of ${ }^{3} \mathrm{H}$ atom of plasma water at $10 \mathrm{~min}$
The relative contribution to the synthesis of body fatty acids of each tissue or organ, expressed in percentage, was computed as follows:

$$
\begin{aligned}
& \mu \mathrm{g} \text { of }{ }^{3} \mathrm{H} \text { atom incorporated } \\
& \text { in to fatty acids } / 10 \mathrm{~min} / \text { tissue } \\
& \begin{array}{c}
\mu \mathrm{g} \text { of }{ }^{3} \mathrm{H} \text { atom incorporated } \\
\text { into fatty acids } / 10 \mathrm{~min} / \text { whole body }
\end{array}
\end{aligned}
$$

The rate of fatty acid synthesis in the whole body was obtained by calculating the sum of the synthesis rates measured in all the tissues and organs, expressed in $\mu \mathrm{g}$ of ${ }^{3} \mathrm{H}$ atom incorporated in to the fatty acids $/ 10 \mathrm{~min} /$ tissue or organ.

\section{RESULTS AND DISCUSSION}

\section{Liver (Table 1)}

In the 7-week old Wistar male rat, the liver was the main site of fatty acid synthesis; it alone synthesized $42 \%$ of all the fatty acids in the body. In rodents, the relative contribution of the liver to body fatty acid synthesis varies $(10-50 \%)$ with the authors (3-9). This variability in results seems to be related to nutritional $(3,14,18,19)$ and genetic $(4,6,8)$ factors which considerably affect the rate of fatty acid synthesis in the liver. The dietary fat content (19), the type of carbohydrate supply (glucose-fructose) (3) and the rhythm of food intake (15, 18 ), in particular, modify the intensity of hepatic fatty acid synthesis. By feeding the animals a low-fat diet $(0.3 \%$, w/w) rich in carbohydrates $(75 \%, w / w, 1 / 3$ of which was sucrose), we created optimal conditions for observing de novo fatty acid synthesis in the liver.

\section{Organs Besides the Liver (Tables 1 and 2)}

The contribution of the 10 organs studied did not exceed. $6 \%$ of the total fatty acid synthesis (Table 1). The kidneys, lungs, heart, stomach, thymus, spleen, brain and testes synthesized little lipids and thus contributed little to body synthesis of fatty acids (Table 3 ). These results agree with data on the mouse (9). The intestines synthesized $2.3 \%$ of the newly formed fatty acids in the body; this contribution was much less (3-10 times) than that found in the mouse $(8,9)$. However, Hollands and Caw thome (9), who reported that the contribution of the intestines to fatty acid synthesis equalled that of the liver in the mouse, did not separate those organs from the mesenteric adipose tissue. This tissue produces much fat, and its presence in the intestines thus leads to a considerable overestimate of their role in fatty acid synthesis. For the same reason, the contribution of the pancreas (1.8\%) to body fatty 
TABLE

Relative Contribution of the Liver, Organs, White Adipose Tissues, Skin and the Rest of the Carcass to Body Fatty Acid Synthesis in the Rata

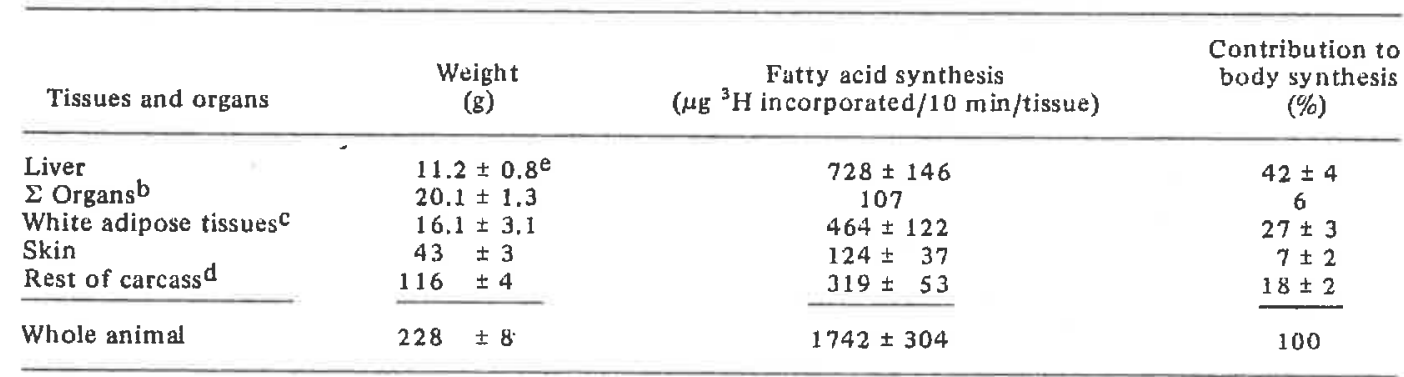

${ }^{a}$ Each rat received $2.5 \mathrm{mCi}$ of ${ }^{3} \mathrm{H}_{2} \mathrm{O}$ by intruperitoneal injection $10 \mathrm{~min}$ before decapitation,

${ }^{b}$ All the organs except the liver (see list in Methods).

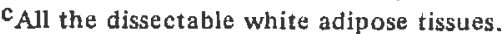

d Mostly the musculature and skeleton.

Mean $\pm \mathrm{SD}$ of 10 assays.

acid synthesis is probably also greatly overestimated in the present paper (Table 3); in fact, rat pancreas being diffuse, it is quite difficult to separate it completely from the mesenteric adipose tissue.

\section{White Adipose Tissues (Tables 1 and 3)}

In our nutritional conditions, the dissectable white adipose tissues represented $7 \%$ of the live weight in the 7 -week old Wistar male rat. Their contribution to body synthesis of fatty acids was $27 \%$, or ca. $50 \%$ of the fat synthesized in the extrahepatic tissues (Table 1). At equal weight, the rate of fatty acid synthesis was, on average, 2.5 times lower in adipose tissues than in the liver. However, this mean value masked a considerable heterogeneity in adipose tissue lipogenic activity which varied according to the anatomical site (Table 3). Thus, the mesenteric adipose tissue alone synthesized $40 \%$ of the labeled fatty acids found in the 6 white adipose tissues studied. At equal weight, the rate of fatty acid synthesis in this tissue was higher than in the other adipose tissue sites studied; it was 2.5-3 times higher than in other inner adipose tissues (epididymal and perirenal) and 6-9 times higher than in the outer adipose tissues (dorsal subcutaneous and inguinal). Most authors recognize that fatty acid synthesis is more intense in the inner than in the outer adipose tissues, whether the rate of synthesis is estimated in vivo with ${ }^{3} \mathrm{H}_{2} \mathrm{O}(11,15)$ and ${ }^{14} \mathrm{C}$ glucose $(20)$ or in vitro with ${ }^{14} \mathrm{C}$-acetate (21). Only Kannan and Baker (22) conclude that their experiments "provide no support for the hypothesis that there is a fundamental difference in the lipogenic capacities of various adipose tissue sites." An examination of the data of these authors (22) (Table 1, p. 48) effectively shows no significant difference in lipogenic capacity between inguinal and popliteal adipose tissues. On the other hand, there are highly significant differences (a) between epididymal and popliteal tissues $(\mathrm{P}<0.001)$, and (b) between epididymal and inguinal tissues $(P<0.01)$. Consequently, when studied closely, Kannan and Baker's data agree with with those of other authors.

In any case, and whatever the experimental conditions, it appears to be impossible to obtain an accurate estimate of the contribution of the adipose tissues to whole body fatty acid synthesis by extrapolating the rate of fatty acid synthesis measured in a particular adipose tissue to the whole of the adipose mass of the animal. However, up to now, all estimates of the contribution of white adipose tissues to overall fatty acid synthesis in the rat have been obtained by this method of calculation $(4,22)$, and therefore the validity of the results proposed should be accepted with great caution. In fact, the exact assessment of the contribution of white adipose tissues to fatty acid synthesis depends on a complete dissection of the main adipose sites of the animal. Using this methodology, frequently applied in the mouse, the contribution of white adipose tissues has been evaluated as $5-30 \%$ of the fatty acid synthesis in the body of the nonobese animal, depending on operative conditions $(8,9)$. To our knowledge, only the present study shows an accurate contribution of the adipose tissues ( $27 \%$ of body synthesis) to the total fatty acid synthesis in the rat. This result is similar to the highest values observed in mouse. 
TABLE 2

Relative Contribution of Different Organs to Body Fatty Acid Synthesis in the Rata

\begin{tabular}{lccc}
\hline Organs & $\begin{array}{c}\text { Weight } \\
(\mathrm{g})\end{array}$ & $\begin{array}{c}\text { Fatty acid synthesis } \\
\left(\mu \mathrm{g}{ }^{3} \mathrm{H} \text { incorporated } / 10 \mathrm{~min} / \mathrm{tiss} \text { ) }\right)\end{array}$ & $\begin{array}{c}\text { Contribution to } \\
\text { body synthesis } \\
(\%)\end{array}$ \\
\hline Intestines & $7.6 \pm 0.4^{b}$ & $41^{\mathrm{c}}$ & 2.3 \\
Kidneys & $1.8 \pm 0.1$ & 9 & 0.5 \\
Lungs & $1.5 \pm 0.1$ & 8 & 0.5 \\
Heart & $1.0 \pm 0.1$ & 2 & 0.1 \\
Stomach & $1.3 \pm 0.1$ & 4 & 0.2 \\
Thymus & $0.6 \pm 0.1$ & 4 & 0.2 \\
Spleen & $0.7 \pm 0.1$ & 1 & 0.1 \\
Brain & $1.9 \pm 0.1$ & 4 & 0.2 \\
Testes & $2.4 \pm 0.2$ & 2 & 0.1 \\
Pancreas & $1.3 \pm 0.1$ & 32 & 1.8 \\
Total & $20.1 \pm 1.3$ & 107 & 6.0 \\
\hline
\end{tabular}

aEach rat received $2.5 \mathrm{mCi}$ of ${ }^{3} \mathrm{H}_{2} \mathrm{O}$ by intraperitoneal injection 10 min before decapitation. $\mathrm{b}_{\text {Mean }} \pm \mathrm{SD}$ of 10 assays.

cowing to the low fat content of the organs, the rate of fatty acid synthesis was measured on pools of the equal amount of dry matter from the same organ of each rat.

\section{TABLE 3}

Relative Contribution of White Adipose Tissues to Body Fatty Acid Synthesis in Relation to Their Anatomical Site in the Rat ${ }^{a}$

\begin{tabular}{|c|c|c|c|c|}
\hline \multirow[b]{2}{*}{ Adipose tissues } & \multirow{2}{*}{$\begin{array}{l}\text { Weight } \\
\text { (g) }\end{array}$} & \multicolumn{2}{|c|}{$\begin{array}{c}\text { Fatty acid synthesis } \\
\left(\mu \mathrm{g}{ }^{3} \mathrm{H} \text { incorporated } / 10 \mathrm{~min} / \mathrm{g} \text { or tissue }\right)\end{array}$} & \multirow{2}{*}{$\begin{array}{l}\text { Contribution to } \\
\text { body synthesis }(\%)\end{array}$} \\
\hline & & /g fresh tissue & whole tissue & \\
\hline Mesenteric & $2.2 \pm 0.5^{\mathrm{C}}$ & $83 \pm 23$ & $183 \pm$ & $10.5 \pm 3.0$ \\
\hline Epididymal & $2.9 \pm 1.0$ & $32 \pm 10$ & $91 \pm$ & $5.2 \pm 2.0$ \\
\hline Perirenal & $2.1 \pm 0.6$ & $28 \pm 5$ & $57 \pm$ & $3.3 \pm 0.4$ \\
\hline Dorsal subcutaneous & $4.6 \pm 0.8$ & $15 \pm 5$ & $70 \pm 19^{\circ}$ & $4.0 \pm 0.9$ \\
\hline Inguinal & $1.8 \pm: 0.6$ & $9 \pm 4$ & $16 \pm 7$ & $0.9 \pm 0.5$ \\
\hline Other adipose tissues ${ }^{b}$ & $2.5 \pm 0.9$ & $19 \pm 9$ & $47 \pm 25$ & $2.7 \pm 1.3$ \\
\hline Total & $16.1 \pm 3.1$ & & $464 \pm 122$ & $26.6 \pm 2.8$ \\
\hline
\end{tabular}

aEach rat received $2.5 \mathrm{mCi}$ of ${ }^{3} \mathrm{H}_{2} \mathrm{O}$ by intraperitoneal injection 10 min before decapitation.

bother adipose tissues $=$ all the cover fat remaining after the inguinal and dorsal subcutaneous tissues were sampled.

cMean \pm SD of 10 assays.

\section{Skin (Table 1)}

The skin contributed $7 \%$ of the body fatty acid synthesis. In the mouse, the skin has a much more important role in this synthesis than in the rat since it contributes $15-30 \%$ of the fatty acids synthesized in the body $(8,9)$.

\section{Rest of Carcass (Table 1)}

The rest of the carcass mostly included the musculature and the skeleton. This whole synthesizes $18 \%$ of the body fatty acids. If the bones are considered as only slightly synthesiz- ing fatty acids (23), the muscles would synthesize, at most, $18 \%$ of the fatty acids in the body; therefore, contrary to data on the mouse $(8,9)$, they are not the main site of fatty acid synthesis in the rat. There is a lively controversy among authors regarding the exact site of muscle lipogenesis, some authors attributing it to the muscle fibers (9) and others to intermuscular adipose tissue $(22,24)$. Although this paper does not supply a direct answer to the question, we think it is more plausible to attribute fatty acid synthesis to the muscle 
fibers themselves than to intermuscular adipose tissues. This hypothesis is based on two observations. (a) The fat content of the rest of the carcass is very low $(54 \mathrm{mg} / \mathrm{g})$ and half constituted of phospholipids, and therefore the intermuscular adipose tissue is probably very little developed. (b) If this adipose tissue was the lipogenic site of the rest of the carcass, its lipogenic capacity (at equal weight) would then be higher than that of all the other tissues and organs (liver or mesenteric adipose tissue included). This does not seem very likely.

To conclude, in 7-week old Wistar male rats fed a low-fat diet ad libitum, the relative contribution of the main tissues and organs to whole body fatty acid synthesis is: liver, $42 \%$; dissectable white adipose tissues, $27 \%$; muscles, $18 \%$; skin, $7 \%$; and organs besides the liver, $6 \%$.

\section{REFERENCES}

1. Windmueller, H.G., and Spaeth, A. (1966) J. Biol. Chem. 241, 2891-2899.

2. Jungas, R.L. (1968) Biochemistry 7, 3708-3717.

3. Romsos, D.R., and Leveille, G.A. (1974) Biochim. Biophys. Acta 360, 1-11.

4. Kannan, R., Learn, D.B., Baker, N., and Elovson, J. (1980) Lipids 15, 993-998.

5. Gandemer, G., Pascal, G., and Durand, G. (1982) Int. J. Biochem. 14, 797-804.

6. Yen, T.L., Allan, J.A., Pao-Lo, Yu, Acton, M.A., and Pearson, D. B. (1976) Biochim. Biophys. Act 441, $213-220$.

7. Lemarchand-Brustel, $Y_{.}$, and Jeanrenaud, $B$.
(1978) Am. J. Physiol. 234, E. 568-E. 574

8. Rath, E.A., and Thenen, S. (1980) Biochim. Biophys. Acta 618, 18-27.

9. Hollands, M.A., and Cawthorne, M.A. (1981) Biochem. J. 196, 645.6.77.

10. Stansbie, D., Brownsey, R.W., Crettaz, M., and Denton, R.M. (1971) Biochem. J. 160,413-416.

11. Godbole, V., and York, D.A. (1978) Diabetologia 14, 191-197.

12. Ganderner, G., Pascal, G, and Durand, G. (1979) Ann. Biol. Anin. Biochim. Miophys. 19, 573-581

13. Pascal, G., Durand, G., Macaire, J.P., and Penot E. (1977) Ann. Biol. Anim. Biochim, Biophys. $17,827-849$.

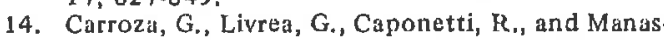
seri, L. (1979) J. Nutr. 109, 162-170.

15. Hems,,$D$, Rath, $E, A$ and Verrinder, T.R. (1975) Biochem. J. $150,167-173$

16. Gandemer, G., Pascal, G., and Durand, G. (1980) C.R. Acad. Sci. Paris 290 (Série D), 1479-1482.

17. Folch, J., Lee, M., und Sloane-Stanley, G.H. (1957) J. Biol, Chem. 226, 487-509.

18. Baker, N., Learn, D.B., and Bruckdorfer, R.K (1978) J. Lipid Res. 19,879-893.

19. Cawthorne, M.A., and Cornish, S. (1979) Int. J. Obesity 3, 83-90.

20. Patkin, J,K., and Masoro, E.J. (1964) Can, J. Physiol. Pharmacol. 42, 101-107.

21. Benjamin, W., Gellhorn, A., Wagner, M., and Kundel, H. (1961) Am. J. Physiol. 201, 540-546.

22. Kannan, R., and Baker, N. (1981) Irudian J. Biochem. Biophys. $18,47-50$.

23. Favarger, P. (1965) Handbook of Physiology (Renold, A.E., and Cahill, G.F., eds.), American Physiological Society, Washington, DC.

24. Kannan, R. Palmquist, D.L., and Baker, $N$ (1976) Biochim. Biophys. Acta 431, 225-232.

[Received May 24, 1982]

LIPIDS, VOL. 18, NO. 3 (1983) 